\title{
Validasi Metode Analisis Cemaran DNA Babi pada Bakso Sapi Menggunakan Primer Mitokondria D-Loop22 dengan Metode Polymerase Chain Reaction (PCR)
}

\author{
(Analysis Method Validation of Pig DNA Contamination in Cow Meatballs Using \\ Mitochondrial Primer D-Loop22 by Polymerase Chain Reaction (PCR) Method)
}

\author{
Sri Wahyuni, Siti Maryam, Aminah \\ Fakultas Farmasi, Universitas Muslim Indonesia, Makassar, Indonesia
}

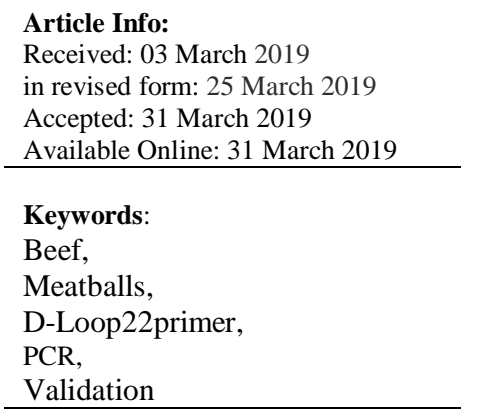

Corresponding Author:

Sri Wahyuni

Fakultas Farmasi

Universitas Muslim Indonesia

Makassar

Indonesia

Email:

sriuni6@gmail.com

\begin{abstract}
The frequency of non-halal ingredient mixing, such as porkin on the food processed products of meatballs, has become an issue to the public, especially for moslems. Therefore, a reliable and valid method with high sensitivity is needed to specifically detect the pig contamination. This research aims to obtain a valid and reliable method by proposing polymerase chain reaction (PCR) using mitochondrial D-Loop22 primer as a method in handing halal food authentication. The sample consisted of beef as a negative control, pork and pork meatballs as a positivecontrol, and five samples of meat balls found in Makassar for halal inspection.The method validation assay was conducted by testing the primary specificity on the fresh tissue (beef and pork) and testing the sensitivity by making a series of pig DNA dilution $\left(1: 10 ; 1: 10^{2} ; 1: 10^{3} ; 1: 10^{4}\right)$ and the variations of contaminated pig:cow $(\% \mathrm{~b} / \mathrm{b}): 0.05 \%, 0.1 \%, 1 \%$, and $5 \%$. The result of PCR amplification on agarose gel electrophoresis of $0.8 \%$ showed that method was able to detect the pig DNA contamination specifically in pigs and not amplify other DNA, and could still be detected up to pig contamination specifically in pigs and not amplify the other DNAs and could still be detected up to pig contamination of $0.05 \%$ and on DNA dilution of $1: 10^{3}$. Meanwhile, on the five samples analyzed, there were not found pig DNA contamination characterized by no formed amplification bands.
\end{abstract}

Copyright (C) 2019 JFG-UNTAD This open access article is distributed under a Creative Commons Attribution (CC-BY-NC-SA) 4.0 International license.

How to cite (APA 6th Style):

Wahyuni. S., Maryam. S., Aminah. (2019). Validasi Metode Analisis Cemaran DNA Babi pada Bakso Sapi Menggunakan Primer Mitokondria D-Loop22 dengan Metode Polymerase Chain Reaction (PCR). Jurnal Farmasi Galenika : Galenika Journal of Pharmacy, 5(1), 65-72. doi:10.22487/j24428744.2017.v3.i1.12035 


\begin{abstract}
ABSTRAK
Maraknya pencampuran bahan non halal seperti daging babi dalam produk olahan makanan seperti bakso sapi, telah banyak meresahkan masyarakat terutama bagi penganut agama islam. Untuk itu diperlukan metode yang handal dan sahih dengan sensitivitas tinggi untuk dapat mendeteksi secara spesifik cemaran babi. Penelitian ini bertujuan untuk memperoleh metode yang valid dan handal dengan mengusulkan metode Polymerase Chain Reaction (PCR) menggunakan primer mitokondria DLoop22 sebagai metode dalam penanganan autentifikasi kehalalan makanan. Sampel penelitian ini terdiri atas daging sapi sebagai kontrol negatif, daging babi dan bakso babi sebagai kontrol positif, serta kelima sampel bakso sapi curah yang diperoleh di wilayah Kota Makassar untuk diperiksa kehalalannya. Uji validasi metode pada penelitian ini dengan menguji spesifitas primer terhadap jaringan segar (daging sapi dan daging babi) dan menguji sensitivitas dengan cara pembuatan serial pengenceran DNA babi (1:10; 1:102; 1:103; 1:104) dan variasi cemaran tiruan babi:sapi $\{0.05 \%$ (b/b); $0.1 \%(\mathrm{~b} / \mathrm{b}) ; 1 \%(\mathrm{~b} / \mathrm{b}) ; 5 \%(\mathrm{~b} / \mathrm{b})\}$. Hasil amplifikasi PCR pada elektroforesis gel agarose $0.8 \%$ menunjukkan bahwa metode ini mampu mendeteksi cemaran DNA babi secara spesifik pada babi dan tidak mengamplifikasi DNA lain, serta masih dapat terdeteksi hingga pada cemaran babi:sapi 0.05\% (b/b) dan pada pengenceran DNA 1:103. Sementara itu, kelima sampel yang dianalisis tidak ditemukan cemaran DNA babi yang ditandai dengan tidak terbentuk pita hasil amplifikasi.
\end{abstract}

Kata Kunci : Bakso sapi, primer D-Loop22, PCR, Validasi

\section{PENDAHULUAN}

Salah satu metode yang cukup akurat untuk mendeteksi cemaran daging babi pada produk pangan adalah dengan menggunakan metode Polymerase Chain Reaction (PCR) (Sari \& Wardani, 2015). Penggunaan primer spesifik untuk babi telah banyak dilakukan oleh beberapa peneliti tahun-tahun terakhir ini (Fatimah, 2013), (Hertanto et al., 2017), (Marlina et al., 2013), (Maryam et al. 2015), (Rahmawati et al, 2016), (Rohman et al., 2017), (Zulfahmi, 2015). Teknologi PCR dengan menggunakan primer mitokondria D-Loop telah dilaporkan oleh Fauziah (2016) yang memiliki sensitivitas tinggi untuk mendeteksi DNA babi dengan sampel kerupuk rambak. Sehingga pendekatan dengan metode PCR menggunakan primer mitokondria D-Loop22 diusulkan sebagai metode analisis dalam pengawasan produk makanan olahan daging. Oleh karena itu Ardi (2012) berpendapat bahwa penelitian terkait validasi atau verifikasi metode-metode analisis diperlukan untuk dapat diterapkan pada masalah cemaran babi dalam produk makanan.

Menurut Sugihartini et al. (2014) validasi terhadap suatu metode analisa menjadi faktor penting karena hanya metode analisa yang telah dibuktikan validitasnya, maka hasil pengukurannya bisa dipertanggung jawabkan dan dipergunakan sebagai landasan dalam perhitungan berikutnya.

Pada penelitian yang dilakukan oleh Raharjo et al. (2017) tentang validasi metode analisis kontaminasi bakso dengan menggunakan primer ND5 secara real time-PCR lebih memfokuskan pada uji validitas spesifikasi, LOD, dan presisi. Metode ini memiliki spesifisitas dan presisi yang tinggi, serta metode ini mampu mendeteksi kontaminasi babi sampai dengan 1\%. Selain itu pada penelitian Raharjo et al. (2017), telah ditemukan bahwa satu dari delapan sampel bakso uji positif terkontaminasi babi.

Berdasarkan pertimbangan tersebut, maka dalam penelitian ini akan dilakukan validasi metode analisis cemaran DNA babi pada bakso sapi menggunakan primer mitokondria D-Loop22 dengan metode PCR untuk membuktikan bahwa metode analisis yang digunakan telah memenuhi semua parameter untuk dapat dijadikan metode yang handal dan sahih dalam analisis cemaran DNA babi pada produk makanan olahan, khususnya bakso sapi dipasaran. 


\section{METODE PENELITIAN}

\section{Alat dan Bahan}

Alat yang digunakan pada penelitian ini adalah gel agarose (CBS Scientific), microwave (Panasonic NNST324M), mikropipet (eppendrotf), sentrifuge sorvall legend micro 17R (Thermo Scientific, USA), translaminator (IVA), neraca analitik (Kern ABT 220 5DM), PCR CFX 96 (Biorad, USA), shaker EFM 60 (OSK, Seiwariko CO,Ltd), spektrofotometer UV-Vis (Thermo Scientefic), vortex (Ika Genius 3), dan waterbath (Memert).

Bahan lain yang digunakan terdiri dari ultrapure agarose (Roche), aqua bidestillata steril, aqua bebas nuclease, dapar lisis, dapar pemuat, dapar TE, dapar TBE (Roche), DNA ladder (Vivantis), enzim Taq green, etanol absolut, etanol 70\%, etidium bromide (EtBr), fenol, kloroform, proteinase $\mathrm{K}$ (Roche), RNAse (Roche) dan primer mitokondria D-Loop22 yang dirancang oleh Fatimah (2013).

\section{Prosedur Kerja}

\section{Sterilisasi Alat dan Bahan}

Sterilisasi alat dan bahan dengan cara membungkus alat-alat, kemudian alat-alat yang tahan terhadap pemanasan disterilkan pada oven pada suhu $180^{\circ} \mathrm{C}$ selama 2 jam, sedangkan alat yang tidak tahan terhadap pemanasan disterilkan pada autoklaf dengan tekanan 1 atm selama 15 menit

\section{Penyiapan Sampel dan Isolasi DNA}

Sampel berupa daging babi segar dan bakso babi disiapkan, digunakan sebagai kontrol positif. serta disiapkan sampel bakso terdiri atas 5 bakso sapi curah dan 1 daging sapi segar. Semua sampel dikumpulkan di wilayah Kota Makassar dengan menggunakan metode populasi terjangkau (accessible population, source population), kemudian diberi label dan disimpan pada suhu $-20^{\circ} \mathrm{C}$ sampai isolasi DNA dilakukan.

Isolasi DNA yang dilakukan sesuai dengan metode Sambrook et al. (1989) dengan beberapa modifikasi. Tiap sampel disiapkan sebanyak 0.2 gram, dicincang hingga halus, kemudian digerus sebelum proses isolasi DNA dilakukan. Hasil isolasi DNA disimpan pada suhu $-20^{\circ} \mathrm{C}$ sampai siap digunakan.

\section{Analisis DNA}

\section{Elektroforesis gel agarosa}

DNA hasil isolasi sebanyak $10 \mu \mathrm{L}$ dianalisis yang telah ditambahkan 2 dapar pemuat, dianalisis secara elektroforesis gel agarose $0.8 \%(\mathrm{w} / \mathrm{v})$ menggunakan dapar TBE dengan pewarna etidium bromide (EtBr) dengan arus 100 Volt selama 60 menit. Gel agarose hasil elektroforesis divisualisasi dengan UVtransluminator dan gambar didokumentasikan.

\section{Pengukuran konsentrasi dan kemurnian DNA}

DNA sebanyak $2 \mu \mathrm{L}$ ditambahkan $998 \mu \mathrm{L}$ aqua bidestillata steril (dalam tube), dihomogenkan. Kemudian diukur dengan spektrofotometer UV pada panjang gelombang 260 dan 280nm. Konsentrasi DNA hasil isolasi dihitung dari $\mathrm{A}_{260}$ dikalikan faktor pengencerannya dan konstanta serapan DNA (serapan DNA murni pada panjang gelombang 260 nm dengan 1 absorbansi unit mengandung $50 \mu \mathrm{g} / \mathrm{mL}$ DNA)

\section{Analisis DNA Babi dengan PCR}

Amplifikasi dengan PCR dilakukan dengan penggunaan campuran reaksi $20 \mu \mathrm{L}$ yang terdiri dari $2 \mu \mathrm{L}$ (50 ng) isolat DNA , $1 \mu \mathrm{L}$ masing-masing primer forward dan reverse (500 nm), dan $6 \mu \mathrm{L}$ aqua bebas nuclease. Pengujian mengikuti kondisi suhu $95^{\circ} \mathrm{C}$ untuk aktivasi enzim/denaturasi awal selama 30 detik, selanjutnya diikuti dengan 30 siklus; $95^{\circ} \mathrm{C}$ selama 5 detik (tahapan denaturasi), $59^{\circ} \mathrm{C}$ selama 30 detik (tahap hibridisasi/annealing), dan $72^{\circ} \mathrm{C}$ selama 10 detik (tahap lanjutan/extension).

\section{Validasi Metode Analisis}

\section{Spesifisitas}

Pengujian spesifisitas dilakukan pada DNA hasil isolasi dari kedua sampel daging mentah (daging babi dan daging sapi)) untuk memverifikasi spesifisitas primer. Selanjutnya dilakukan pencampuran DNA genom dengan DNA primer forward dan reverse yang tersedia. Percobaan ini bertujuan untuk menghasilkan pengujian yang cepat, ekonomis dan simultan untuk keaslian daging. 


\section{Sensitivitas}

Pengujian sensitivitas dilakukan dengan membuat seri pengenceran DNA template dari daging babi yang digunakan. Pengenceran dibuat dengan empat deret konsentrasi $\left(1: 10 ; 1: 10^{2} ; 1: 10^{3}\right.$; dan $\left.1: 10^{4}\right)$, serta dibuat cemaran tiruan dari daging babi dalam daging sapi dengan rasio sebagai berikut: 0.05\% (b/b); 0.1\% (b/b); $1 \%$ (b/b); dan 5\% (b/b). Percobaan ini dilakukan untuk mengetahui kepekaan (sensitivitas) dalam mendeteksi pemalsuan daging dipasaran.

\section{HASIL DAN PEMBAHASAN}

Pada tahap penelitian ini, dilakukan terlebih dahulu isolasi DNA dari tiap sampel yang dianalisis. Tahapan ini bertujuan untuk mendapatkan DNA template dari tiap sampel. Hasil molekul DNA yang telah diisolasi divisualisasi dan dianalisis dengan menggunakan elektroforesis gel agarose $0.8 \%$ untuk memastikan bahwa molekul DNA dari sampel telah terisolasi atau tidak. Pada Gambar 1, Gambar 2, Gambar 3 menunjukkan hasil isolat DNA. Dari hasil elektroforegram (Gambar 1, Gambar 2 dan Gambar 3), terlihat bahwa isolat yang dihasilkan cukup baik yang ditandai dengan terisolasinya molekul DNA.

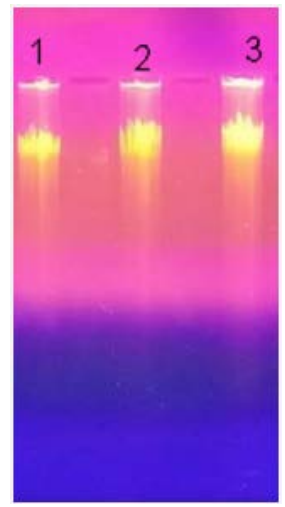

Gambar 1. Hasil elektroforesis isolasi DNA dari daging sapi dan babi sebelum dilakukan PCR

Keterangan: 1. Daging sapi (U), 2. Daging Babi (A4), 3. Daging babi (Y3)

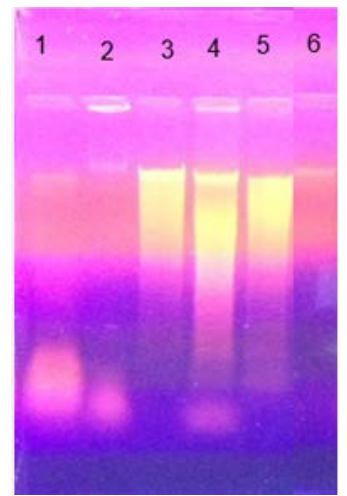

Gambar 2. Hasil elektroforesis isolasi DNA dari sampel bakso sapi dan babi sebelum dilakukan PCR

Keterangan: 1. [Bakso sapi curah a (I5)]; 2. [Bakso sapi curah b (E7)]; 3. [Bakso sapi curah c (F9)]; 4. [Bakso sapi curah d (G10)]; 5. [Bakso sapi curah e (H10)]; 6. (Bakso babi)

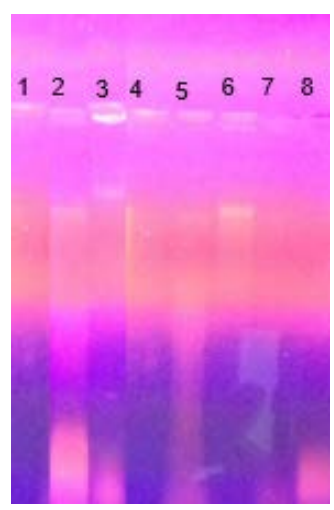

Gambar 3. Hasil elektroforesis isolasi DNA

Keterangan: 1. [babi:sapi 0.1\% (b/b)]; 2. [babi:sapi 5\% (b/b)]; 3. [babi:sapi 1\% (b/b)]; 4. [babi:sapi 0.05\% (b/b)]; 5. [pengenceran DNA babi 1:10]; 6. [pengenceran DNA babi $1: 10^{3}$ ]; 7 . [pengenceran DNA babi 1:10 ${ }^{4}$ ]; 8 . [pengenceran DNA babi 1:10²]

Tahapan selanjutnya adalah penentuan konsentrasi dan kemurnian DNA hasil isolasi dengan menggunakan spektrofotometer UV-Vis pada panjang gelombang $260 \mathrm{~nm}$ dan $280 \mathrm{~nm}$. Panjang gelombang $260 \mathrm{~nm}$ digunakan dalam penelitian ini, karena pada panjang gelombang tersebut daya serapan sinar oleh nukleotida maksimal. Sedangkan penyerapan maksimal oleh protein dicapai pada panjang gelombang $280 \mathrm{~nm}$ (Tenrilulo, Suryati, Parenrengi dan Rosmiat 2017, h. 8).

Berdasarkan penelitian yang telah dilakukan terhadap tingkat kemurnian dan konsentrasi DNA hasil isolasi, diperoleh data yang telah disajikan pada Tabel 1, 
Tabel 2 dan Tabel 3. Hasil kuantitatif menunjukkan bahwa kemurnian DNA yang diperoleh dari isolat DNA, hanya sampel berkode U (Tabel 1), E7 dan F9 (Tabel 2) yang memenuhi indeks kemurnian DNA yang baik. Menurut Fatchiyah (2011), indeks kemurnian DNA yang baik berkisar antara 1.8-2.0. Sedangkan kode sampel lainnya berada dibawah range kemurnian. Apabila nilai kemurnian yang diperoleh dibawah 1.8 menunjukkan bahwa DNA masih terdapat kontaminan berupa protein dan polisakarida. Sedangkan jika nilainya diatas 2.0 menunjukkan bahwa DNA masih terkontaminasi fenol. Hal ini dikarenakan fenol memiliki serapan maksmial di panjang gelombang $260 \mathrm{~nm}$ (Farmawati et al, 2015).

Tabel 1. Hasil uji kuantitatif spektrofotometer UVVis isolat DNA daging sapi dan daging babi

\begin{tabular}{ccc}
\hline $\begin{array}{c}\text { Kode } \\
\text { Isolat }\end{array}$ & $\begin{array}{c}\text { Konsentrasi } \\
(\mu \mathrm{g} / \mathrm{mL})\end{array}$ & $\begin{array}{c}\text { Kemurnian } \\
(\mathrm{A} 260 / \mathrm{A} 280)\end{array}$ \\
\hline $\mathrm{U}$ & 775 & 2.06 \\
$\mathrm{~A} 4$ & 350 & 1.4 \\
$\mathrm{Y} 3$ & 1975 & 1.112 \\
\hline
\end{tabular}

Keterangan: (1) daging sapi (U), (2) daging babi (A4), (3) daging babi (Y3)

Tabel 2.Hasil Uji Kuantitatif spektrofotometri UVVis isolat sampel bakso sapi dan bakso babi

\begin{tabular}{ccc}
\hline $\begin{array}{c}\text { Kode } \\
\text { Isolat }\end{array}$ & $\begin{array}{c}\text { Konsentrasi } \\
(\mu \mathrm{g} / \mathrm{mL})\end{array}$ & $\begin{array}{c}\text { Kemurnian } \\
(\mathrm{A} 260 / \mathrm{A} 280)\end{array}$ \\
\hline I5 & 1700 & 1.658 \\
E7 & 525 & 1.9 \\
F9 & 100 & 2.0 \\
G10 & 725 & 1.705 \\
H10 & 675 & 1.5 \\
Z3 & 975 & 1.56 \\
\hline
\end{tabular}

Keterangan: (1) bakso curah a (I5), (2) bakso curah b (E7), (3) bakso curah c (F9), bakso curah d (G10), (4) bakso curah e (H10), (6) bakso babi

Tabel 3. Hasil Uji Kuantitatif spektrofotometri UVVis sampel cemaran tiruan

\begin{tabular}{ccc}
\hline $\begin{array}{c}\text { Kode } \\
\text { Isolat }\end{array}$ & $\begin{array}{c}\text { Konsentrasi } \\
(\mu \mathrm{g} / \mathrm{mL})\end{array}$ & $\begin{array}{c}\text { Kemurnian } \\
(\mathrm{A} 260 / \mathrm{A} 280)\end{array}$ \\
\hline $\mathrm{WC}$ & 150 & 1.2 \\
\hline $\mathrm{WD}$ & 300 & 1.714 \\
\hline $\mathrm{WE}$ & 575 & 1.642 \\
\hline $\mathrm{WF}$ & 850 & 1.545 \\
\hline
\end{tabular}

Keterangan:(1) campuran babi:sapi 0.05\% (b/b) (WC), (2) campuran babi:sapi $0.1 \%(\mathrm{~b} / \mathrm{b})$ (WD), (3) campuran babi:sapi 1\% (b/b) (WE), (4) campuran babi:sapi 5\% (b/b) (WF)
Menurut rekomendasi KapaBiosystems tahun 2014 yang dikutip oleh Nugroho et al. (2017), konsentrasi DNA template yang dibutuhkan untuk kegiatan PCR berkisar antara 10-100 $\mu \mathrm{g} / \mu \mathrm{L}$, sehingga konsentrasi DNA total yang diperoleh pada metode ini telah mencukupi untuk dapat digunakan dalam proses PCR. Secara keseluruhan konsentrasi DNA yang diperoleh memiliki kuantitas yang berbeda-beda mulai dari 100 sampai $1975 \mu \mathrm{g} / \mu \mathrm{L}$. Untuk itulah dilakukan penyeragaman konsentrasi dengan pengenceran DNA sesuai dengan konsentrasi optimal dalam amplifikasi PCR. Menurut Maryam (2014), konsentrasi optimal dalam amplifikasi PCR pada 30 siklus untuk menghasilkan pita yang tebal adalah konsentrasi $50 \mu \mathrm{g} / \mu \mathrm{L}$ baik pada pembanding daging sapi, daging babi, dan sampel bakso sapi serta bakso babi.

Seluruh isolat DNA yang telah melewati proses pengujian analisis kuantitatif dan memenuhi ketentuan yang ada. Selanjutnya dapat digunakan pada analisis molekular berbasis PCR. PCR merupakan metode yang dipilih pada penelitian ini karena efisiensi serta sensitivitas yang tinggi dalam mendeteksi secara akurat, walaupun nilai kemurnian yang diperoleh berada dibawah range yang ditetapkan. Adapun komponen lain yang diperlukan selain DNA template pada kegiatan ini, yaitu primer. Pada penelitian ini, primer yang digunakan merupakan primer mitokondria D-Loop22 yang terletak pada daerah d-loop, yang spesifik hanya menghasilkan satu pita dengan ukuran tertentu dan hanya mengamplifikasi DNA babi. Penggunaan primer babi dimaksudkan untuk mengetahui ada atau tidaknya keberadaan kontaminan DNA babi didalam produk olahan daging yang diuji yaitu bakso sapi.

Proses PCR dimulai dengan tahap denaturasi yang dilakukan pada suhu $95^{\circ} \mathrm{C}$ selama 30 detik, pada langkah ini, heliks ganda DNA terurai menjadi dua untai cetakan DNA tunggal, penempelan primer (anneling) pada suhu $59^{\circ} \mathrm{C}$. Menurut Rahmawati et al. (2016) berdasarkan hasil optimasi suhu anneling, diperoleh bahwa suhu optimum anneling pada primer mitokondria D-Loop22 yaitu pada suhu $59^{\circ} \mathrm{C}$ dengan menggunakan metode real-time PCR. Pada suhu tersebut dapat secara spesifik mengidentifikasi target DNA babi diantara DNA sapi, ayam, kambing dan kuda. Oleh karena itu, pada penelitian ini digunakan suhu anneling $59^{\circ} \mathrm{C}$ selama 30 detik. Anneling merupakan parameter penting untuk keberhasilan hasil produk PCR. Tahap selanjutnya yaitu tahap 
extension berlangsung pada suhu $72^{\circ} \mathrm{C}$, pada tahap ini terjadi proses polimerasi untuk pembentukan untai DNA baru (Fatchiyah, 2011).

Berdasarkan hasil elektroforegram (Gambar 4), menunjukkan bahwa metode PCR menggunakan primer D-Loop22 pada pengujian validasi metode dengan parameter uji spesifitas dari kedua daging mentah yaitu daging sapi dan daging babi dapat dilihat pada lajur 6 dan 7. Primer ini dapat dikatakan memiliki spesifitas yang baik, ditunjukkan dari lajur 6 (daging sapi) dan 7 (daging babi) yang mana hanya lajur 7 menghasilkan pita dan berada dibawah DNA ladder. DNA ladder merupakan DNA standar yang telah diketahui ukurannya (250-10000 bp) yang digunakan dalam penentuan ukuran fragmen dengan membandingkan mobilitas fragmen DNA yang dihasilkan.

Pada pengujian sensitivitas yang meliputi dua tahapan, pada tahap pertama digunakan satu isolat DNA daging babi yang diencerkan konsentrasinya menjadi $1: 10,1: 10^{2}, 1: 10^{3}$ dan $1: 10^{4}$ dengan menggunakan isolat berkode Y3. Hasil elektroforegram (Gambar 6) dapat dilihat pada bagian lajur 1 sampai 4. Dari kelima deret pengenceran menghasilkan pita yang beragam. Namun hasil pita yang paling jelas terlihat pada lajur 4 yaitu 1:10 dan sudah tidak menghasilkan pita pada pengenceran $1: 10^{4}$ (lajur 1). Pita yang sudah tidak dapat dilihat dengan jelas, kemungkinan karena konsentrasi yang dihasilkan pengenceran terlalu rendah untuk digunakan pada proses PCR, sehingga sudah tidak mampu mengamplifikasi.

Pada tahap kedua, dilakukan variasi cemaran tiruan daging babi dalam daging sapi dengan persentase $0.05 \%, 0.1 \%$, $1 \%$, dan $5 \%$ yang dapat dilihat pada bagian lajur 1 sampai 4 (Gambar 5) yang menunjukkan kesensitivitisan primer babi dalam mendeteksi DNA babi sampai konsentrasi $0.05 \%$ (lajur 1). Sementara hasil pita yang dihasilkan tampak sangat tipis seiring dengan berkurangnya konsentrasi cemaran DNA babi. Ketebalan pita yang lebih besar ditunjukkan pada lajur 4 (Gambar 5 dan Gambar 6). Sedangkan pita lajur lain menunjukkan pita yang tunggal, kurang terang, dan tidak utuh. Namun hal ini, bukan hanya dipengaruhi oleh desain primer serta variasi konsentrasi yang digunakan, tetapi bisa saja disebabkan oleh kesalahan teknis saat proses preparasi sampel, dikarenakan telah terjadi degradasi atau fragmentasi sehingga pita DNA tipis dan tidak terlihat dengan jelas, serta metode ekstraksi DNA yang digunakan.

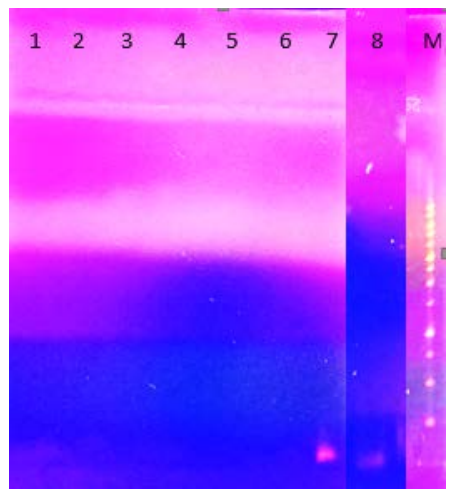

Gambar 4. Hasil amplifikasi PCR yang dielektroforesis pada gel agarosa $0.8 \%$.

Keterangan: 1. [Bakso sapi curah a (I5)]; 2. [Bakso sapi curah b (E7)]; 3. [Bakso sapi curah c (F9)]; 4. [Bakso sapi curah d (G10)]; 5. [Bakso sapi curah e (H10)]; 6. (Daging sapi); 7. (Daging babi); 8. (Bakso babi); M (Marker)

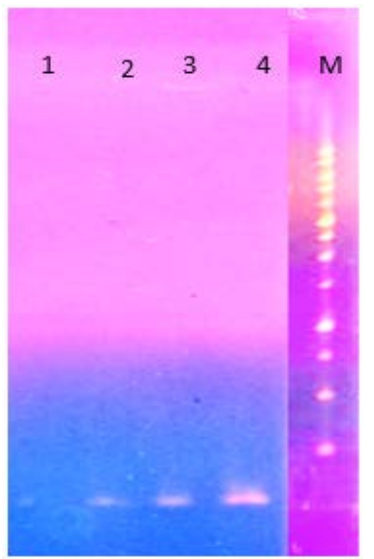

Gambar 5. Hasil amplifikasi PCR yang dielektroforesis pada gel agarosa $0.8 \%$. Keterangan: 1. ([babi:sapi] $0.05 \%$

(b/b)); 2. (([babi:sapi] 0.1\% (b/b)) 3. ([babi:sapi] 1\% (b/b)); 4. (([babi:sapi] 5\% (b/b)); M (Marker) 


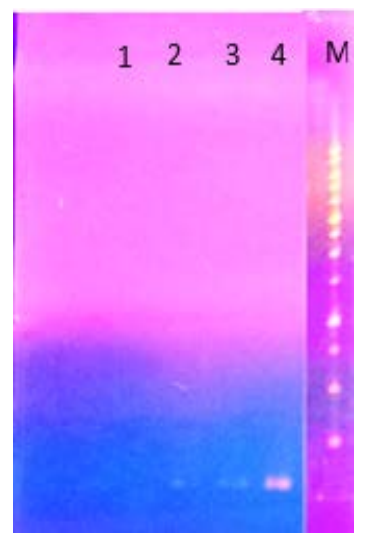

Gambar 6. Hasil amplifikasi PCR yang dielektroforesis pada gel agarosa $0.8 \%$.

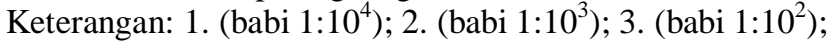
4. (babi 1:10); M (Marker)

Pada pengujian terhadap produk bakso sapi curah yang diambil pada beberapa wilayah di Makassar, semua sampel uji diperiksa menggunakan primer mitokondria D-Loop22 (Gambar 4) dengan daging sapi sebagai kontrol negatif, sementara daging babi dan bakso babi sebagai kontrol positif. Berdasarkan hasil elektroforegram pada Gambar 4 menunjukkan bahwa semua sampel dari lajur 1 sampai 5 dengan kode sampel I5, E7, F9, G10, dan H10 tidak menghasilkan pita dan hanya kontrol positif yang nampak pita dengan ukuran yang sama (lajur 7 dan 8) setelah dielektroforesis. Hal ini mengindikasikan bahwa sampel bakso sapi curah di wilayah Kota Makassar aman dikonsumsi dan tidak mengandung cemaran DNA babi.

\section{KESIMPULAN}

Berdasarkan penelitian yang telah dilakukan dapat disimpulkan bahwa:

1. Primer D-Loop22 merupakan primer yang spesifik hanya mengamplifikasi DNA babi dan tidak mengamplifikasi DNA lain hingga cemaran 0.05\% (b/b) dan pada serial pengenceran DNA Babi 1:103.

2. Sampel bakso sapi yang terdapat di wilayah Makassar tidak mengandung DNA babi.

\section{DAFTAR PUSTAKA}

Ardi, A. (2012). Validasi metode ekstraksi DNA pada analisis DNA babi dalam produk bakso, [Skripsi]. Fakultas MIPA. Institut Pertanian Bogor. Bogor.
Farmawati, D.A., Wirajana, N., \& Yowani, S.C. (2015). Perbandingan Kualitas DNA dengan menggunakan Metode Boom Original dan Boom Modifikasi pada Isolat Mycobacterium tuberculosis 151. KIMIA, vol. q, pp. 41-45.

Fatchiyah,. Aruminingtyas, E.L., Widyarti, S., \& Rahayu, S. (2011). Biologi Molekuler-Prinsip Dasar Analisis. Erlangga, Malang.

Fatimah, S. (2013). Deteksi Cemaran Daging Babi dalam Campuran Bakso Ayam dengan RealTime PCR dan Spektrofotometri FTIR, [Tesis], Fakultas Farmasi, Universitas Gadjah Mada, Yogyakarta.

Fauziah, A.R. (2016). Identifikasi Cemaran Kulit Babi pada Kerupuk Rambak dengan Metode Real-Time Polymerase Chain Reaction menggunakan Primer Mitokondria D-Loop 22', [Skripsi], Fakultas Farmasi, Universitas Gadjah Mada, Yogyakarta.

Hertanto, B.S., Fitra, R.A., Kartikasari, L.R., \& Cahyadi, M. (2017). Authentication of Raw Chicken Mear from Pork Contamination using Gene CYT-B with Duplex-Polymerase Chain Reaction Analysis, Buletin Peternakan, vol. 41, pp. 113-118

Marlina, Mutalib, S.A., Islami, Sari, H.K., \& Fitria, A. (2013). Pengembangan Metode PCR dan Southern Hybridization untuk Deteksi Gen Babi pada Cangkang Kapsul. Pros. Semin. Nas. Perkemb. Terkini Sains Farm. Dan Klin. III, pp. 116-121

Maryam, S. (2014). Analisis Cemaran DNA Babi Pada Dendeng menggunakan primer mitokondria D-Loop686 dan gen cyt b dengan menggunakan Real time polymerase chain reaction (real time PCR), [Tesis], Fakultas Farmasi. Universitas Gadjah Mada, Yogyakarta.

Maryam, S., Sismindari, Raharjo, T.J., Sudjadi, Rohman, A. (2015). Determination of Porcine Contamination in Laboratory Prepared dendeng Using Mitochondrial D-Loop686 and cyt $b$ Gene Primers by Real Time Polymerase Chain Reaction, International Journal of Food Properties, vol.19, no. 11, pp. 187-195. 
2017,https://doi.org/10.1080/10942912.2015.1 020434

Nugroho, K., Terryana, R.T., dan Lestari, P. (2017). Metode Ekstraksi DNA Cabai (Capsicum annuum L.) menggunakan Modifikasi Buffer CTAB (Cethyl Trimethyl Ammonium Bromide) tanpa Nitrogen Cair, Scripta Biologi, vol. 4, no. 2, pp. 91-94

Raharjo, T.J., Alfiraza, E.N., Enjelina, E., \& Pranowo, D. (2017). Validation of a NonSpecific Dye Real-Time PCR Assay for Porcine Adulteration in Meatball Using ND5 Primer, Indones. J. Chem, vol. 17, no.2, pp. 167-174.

Rahmawati, Sisimindari, Raharjo, T.J., Sudjadi, \& Rohman, A. (2016). Analysis of Pork Contamination in Abon using Mitochondrial D-Loop 22 primer Using Real-Time Polymerase Chain Reaction Method, International Food Research Journal, vol. 23, pp. 370-374.

Rohman, A., Himawati, A., Triyana, K., Sismindari, \& Fatimah, S. (2017. 'Identification of Pork in Beef Meatballs using Fourier Transform Infrared Spectrophotometry and Real-time Polymerase Chain Reaction, International Journal of Food Properties, vol. 20, pp. 654661.
Sambrook, J., Fritsch, E.F., \& Maniatis, T. (1989). Molecular Cloning: A Laboratory Manual, Cold Spring Harbor Laboratory Press, pp. 626.

Sugihartini, N., Fudholi, A., Pramono, S., \& Sismindari, S. (2014). Validasi Metode Analisa Penetapan Kadar Epigalokatekin Galat dengan Kromatografi Cair Kinerja Tinggi, Pharmaciana, vol. 4, no. 1, pp. 39-44.

Tenriulo, A., Suryati, E., Parenrengi, A., \& Rosmiati. (2001). Ekstraksi DNA Rumput Laut Rappaphycus alvarezil dengan metode Fenol Kloroform', Marina Chimica Acta, vol. 2, no. 2, pp. 6-10

Zulfahmi. (2015). Deteksi Kontaminan Babi Pada Produk Makanan Menggunakan Teknologi DNA Molekuler, Kutubkhanah: J. Penelit. Sos. Keagamaan, vol. 18, no. 1, pp. 